\title{
Modelling and Simulation of Phase Formations in Martensitic Stainless Steels
}

\author{
Simona Kresser ${ }^{1,3}$, Reinhold Schneider' ${ }^{1}$, Horst Zunko², and Christof Sommitsch ${ }^{3}$ \\ ${ }^{1} \mathrm{FH}$-OÖ Forschungs- \& Entwicklungs $\mathrm{GmbH}$, Wels, Austria \\ ${ }^{2}$ voestalpine Böhler Edelstahl GmbH \& CoKG, Kapfenberg, Austria \\ IInstitute of Materials Science, Joining and Forming, Graz University of Technology, Graz, Austria
}

Received November 15, 2021; accepted November 23, 2021; published online December 16, 2021

\begin{abstract}
Modelling and simulation of solidification processes and solid-state phase transformation have become key instruments in the field of alloy development and heat treatment optimization. Apart from equilibrium-controlled processes, also diffusion-based effects need to be considered. This contribution presents some typical approaches at the example of martensitic stainless steels. Important aspects affecting the production and properties of these steels, such as alloying limits with nitrogen, the formation of ledeburitic structures, or the retained austenite content after heat treatment, can be predicted with reasonable accuracy.
\end{abstract}

Keywords: Martensitic stainless steels, Modelling, Microstructure, Retained austenite, Partitioning

Modellierung und Simulation von Phasenumwandlungen in korrosionsbeständigen martensitischen Stählen

Zusammenfassung: Modellierung und Simulation von Erstarrungsvorgängen und Phasenumwandlungen im festen Zustand sind heute übliche Instrumente im Bereich der Legierungsentwicklung und der Optimierung von Wärmebehandlungsprozessen. Neben gleichgewichtskontrollierten Prozessen müssen diffusionsbedinge Vorgänge berücksichtig werden. Nachfolgend werden typische Ansätze am Beispiel korrosionsbeständiger martensitischer Stähle vorgestellt. Wesentlich Aspekte, welche die Herstellung und Eigenschaften dieser Stähle beeinflussen, wie die Legierungsgrenzen mit Stickstoff, die Ausbildung ledeburitischer Strukturen oder der Restaustenitgehalt nach der Wärmebehandlung, können gut vorhergesagt werden.

DI S. Kresser (ه)

FH-OÖ Forschungs- \& Entwicklungs $\mathrm{GmbH}$,

Stelzhamerstraße 23,

4600 Wels, Austria

Simona.Kresser@fh-wels.at
Schlüsselwörter: Korrosionsbeständige martensitische Stähle, Modellierung, Gefüge, Restaustenit, Partitioning

\section{Introduction}

Martensitic stainless steels are an important group of steels with a wide field of applications ranging from mechanical components, knifes, and medical instruments to moulds for plastic processing and corrosion resistant bearings. While some grades have been used in similar composition for one century, other newly developed grades such as reported in [1-3] are optimized for specific applications. Modelling of microstructural changes is an important tool for the design and heat treatment of these steels and for understanding certain phenomena taking place. Therefore, different types of calculation methods are in use to predict different aspects, microstructures, processes or properties.

\section{Used Alloys, Software, Models, and Experimental Procedures}

For the verification of the simulation results as well as for the determination of factors for the empirical formulas used in the models, six different alloys with the chemical composition shown in Table 1 were used. These steels can be classified into three sub-groups:

1. Cr-C-based matrix steels with usually low carbide content (X40Cr14, X38CrMo16)

2. Cr-C-based carbide rich wear resistant steel (X90CrMoV18, X105CrMo17)

3. Cr-C-N-based, steels (X40CrMoVN16-2, X30CrMoN15-1)

The chemical compositions cover a wide range of martensitic stainless steels $(13-18 \% \mathrm{Cr}, 0.2-1 \% \mathrm{C}$ up to $2 \%$ Mo, up to $0.4 \% \mathrm{~N}$ ) and provide of sound base to assess different aspects of this steel group. 


\begin{tabular}{|c|c|c|c|c|c|c|c|c|c|c|}
\hline Short & EN ISO & Mat. No & C & $\mathrm{N}$ & $\mathrm{Cr}$ & Mo & $\mathrm{Si}$ & $\mathrm{Mn}$ & Others & k-faktor \\
\hline $1 \mathrm{a}(14 / 0)$ & $\mathrm{X} 40 \mathrm{Cr} 14$ & 1.2083 & 0.36 & 0.02 & 14.2 & - & 0.7 & 0.4 & $0.2 \mathrm{~V}$ & 0.016 \\
\hline $1 b(16 / 1)$ & X38CrMo16 & 1.2316 & 0.35 & 0.04 & 15.7 & 0.9 & 0.4 & 0.7 & $0.7 \mathrm{Ni}$ & 0.022 \\
\hline $2 a(18 / 1)$ & X90CrMoV18 & 1.4112 & 0.87 & 0.03 & 17.8 & 1.0 & 0.6 & 0.6 & $0.1 \mathrm{~V}$ & 0.017 \\
\hline $2 b(17 / 0)$ & X105CrMo17 & 1.4125 & 1.02 & 0.02 & 16.3 & 0.4 & 0.4 & 0.3 & - & 0.018 \\
\hline $3 a(16 / 2)$ & X40CrMoVN16-2 & 1.4123 & 0.42 & 0.21 & 15.5 & 1.8 & 0.2 & 0.5 & $0.3 \mathrm{~V}$ & 0.017 \\
\hline $3 b(15 / 1)$ & X30CrMoN15-1 & 1.4108 & 0.30 & 0.39 & 15.0 & 1.0 & 0.5 & 0.4 & $0.1 \mathrm{~V}$ & 0.020 \\
\hline
\end{tabular}

For thermodynamic calculations, the Software Thermocalc ${ }^{\circledR}$ with the data base TCFe9 was used. The predictions of the $M_{s}$ temperatures were calculated using a new $M_{s}$ formula described below. The martensite transformation was calculated with the approach of Koistinen-Marburger [4], for which the k-factors listed in Table 1 were used. The k-factors are experimentally determined average values of the specific alloys and are in good agreement with the factor 0.015 for the steel $\mathrm{X} 20 \mathrm{Cr} 13$ documented in [5].

For the prediction of the retained austenite content due to partitioning phenomena, a "Constrained Carbon Equilibrium" CCE model from [6,7] was used and modified as described in more detail in [8]. The new model considers partial partitioning, as reported in [9], and was extended towards nitrogen using the same partitioning factor.

Heat treatment experiments were conducted using samples of $10 \times 4 \times 3 \mathrm{~mm}^{3}$ and a Bähr $805 \mathrm{~A} / \mathrm{D}$ pushrod dilatometer. The $M_{s}$ temperatures were determined by the intersection method. Samples were embedded, ground, and polished for the retained austenite determination by XRD according to ASTM E975-13 using a Bruker D8 Advance diffractometer. For the microstructural investigations, the etching agent Carapella from [10] was used. More detailed information can be found in [8].

\section{Prediction of the Solidification Behaviour}

\subsection{Liquid-solid Phase Transformation Under Equilibrium Conditions}

The predicted phase transformation during solidification is shown in Fig. 1. While, with low $\mathrm{C}$ and $\mathrm{N}$ contents, a peritectic solidification with $\delta$-Ferrite formation is dominant, high $C$ contents lead to a ledeburitic reaction which includes the formation of large $\mathrm{M}_{7} \mathrm{C}_{3}$ carbides. Nitrogen clearly supports the primarily austenitic solidification. Increasing the chromium content (Fig. 1a) enhances both the peritectic as well as the ledeburitic reaction. The effect of molybdenum (Fig. 1b) is similar and acts towards the same direction. Practically all technical alloys are subject to a partly peritectic solidification, but a ledeburitic reaction can be expected only for high-C-steels.

\subsection{Phase Transformations Considering Partial Diffusion}

As the formation of ledeburitic carbides is essential for the materials properties and beneficial for wear resistance but detrimental for toughness, a more accurate description of the solidification behaviour is necessary. Permitting full equilibration by diffusion for $\mathrm{C}$ and $\mathrm{N}$ but no equilibration
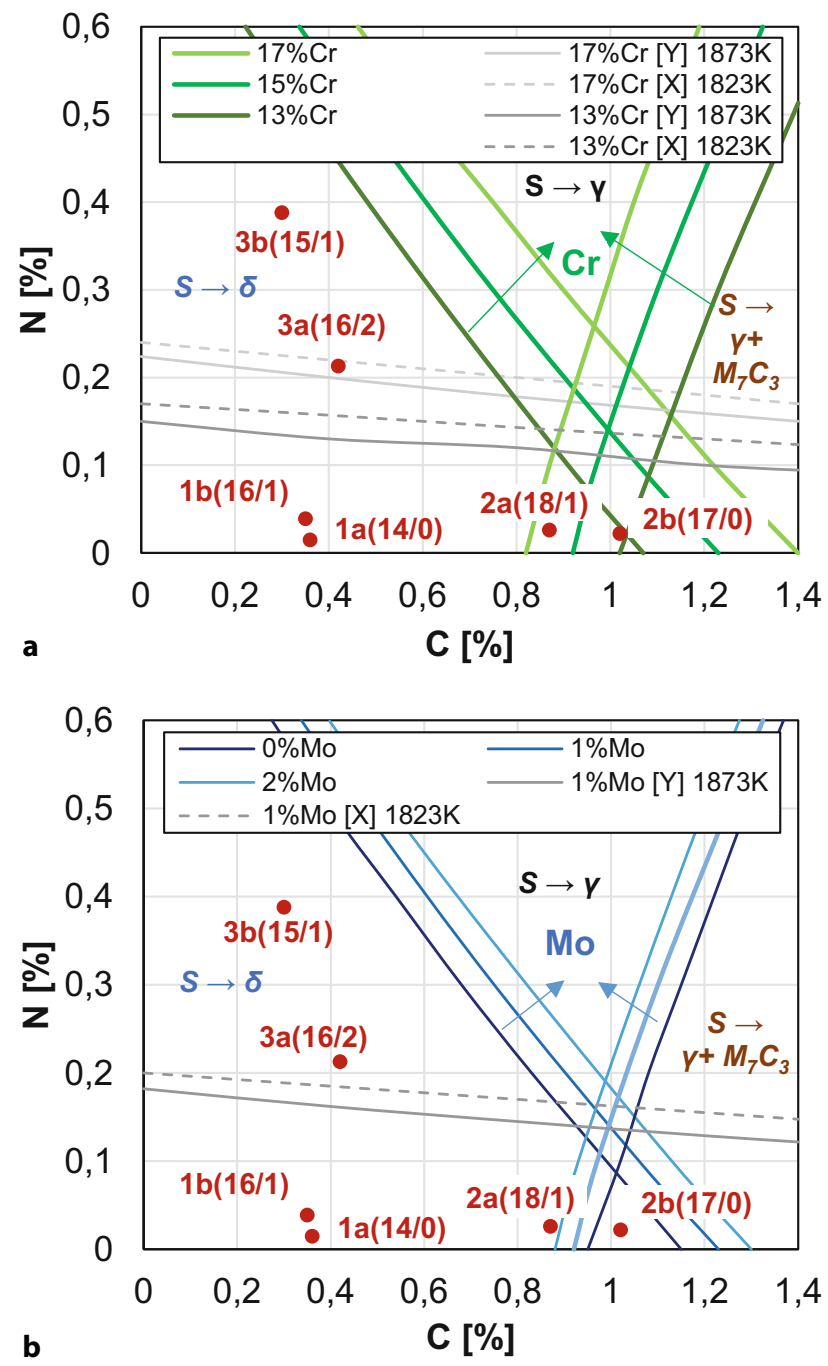

Fig. 1: Effect of $\mathrm{C}$ and $\mathrm{N}$ on $\delta$-Ferrite formation and ledeburitic reactions as well as on $\mathrm{N}$ solubility in $\mathrm{Fe}$ ( 1 bar) a effect of $\mathrm{Cr}$ (at $1 \% \mathrm{Mo}, 0.5 \% \mathrm{Si}, \mathrm{Mn}$ each), b effect of $\mathrm{Mo}$ (at $15 \% \mathrm{Cr}, 0.5 \% \mathrm{Si}, \mathrm{Mn}$ each) 
for the other elements (Scheil Solidification Simulation), the formation of ledeburite (LB) is shifted to significantly lower carbon contents (Fig. 2). Similar to the equilibrium calculations, a clear shift to higher ledeburite fractions with rising $\mathrm{Cr}$ contents is evident.

Under these conditions, all six commercial alloys are prone to forming at least small amounts of ledeburite. The lowest values can be expected in the high nitrogen grade $\mathrm{X} 30 \mathrm{CrMoN} 15-1$ (1-2\%) followed by the matrix steels $\mathrm{X} 40 \mathrm{Cr} 14$ and $\mathrm{X} 38 \mathrm{CrMo16}$ (2-3\%). A similar amount of about $3 \%$ ledeburite is predicted for grade $\mathrm{X} 40 \mathrm{CrMoVN16-2}$. In case of the high carbon containing steels X90CrMoV18 and $\mathrm{X} 105 \mathrm{CrMo17}$, up to about $15 \%$ ledeburitic solidification is forecasted. It should be noted that, in case of high nitrogen contents, the ledeburitic reaction leads not only to carbides but also to nitrides.

\subsection{Nitrogen Solubility and Outgassing}

High nitrogen contents of up to $0.6 \%$ shown in Figs. 1 and 2 are only possible with high pressure metallurgy. To make an estimation about which nitrogen contents can be achieved under atmospheric conditions, different calculation methods as evaluated in [11] for austenitic grades can be applied. In Fig. 1 the solubility limits according to formulas by Stein and Menzel [12] for $1600^{\circ} \mathrm{C}$ and Medovar et al. [13] for $1550^{\circ} \mathrm{C}$ are additionally indicated. The results confirm the positive effects of higher $\mathrm{Cr}$ contents and lower melting temperatures and the limiting impact of $C$ on the nitrogen solubility. The nitrogen alloyed grade X40CrMoVN16-2 is evidently at the upper limit of nitrogen alloyed steels for conventional production routes.

While getting high nitrogen contents into the steel is one challenge, keeping it in solution during solidification without a massive void formation and corresponding outgassing is another. These calculated limits are indicated in Fig. 2. Again, higher $\mathrm{Cr}$ contents are beneficial, especially with higher carbon contents, whereby carbon, as an

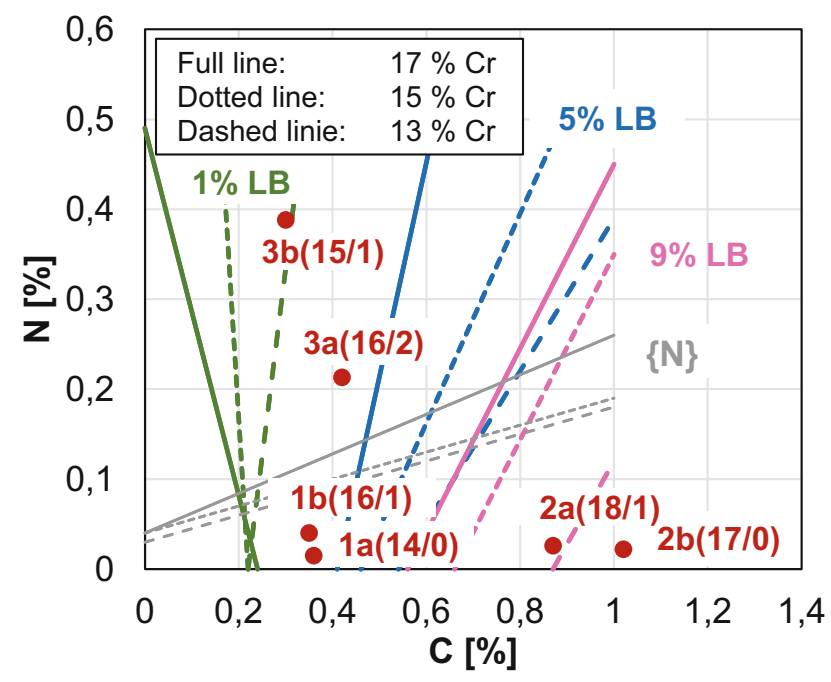

Fig. 2: Effect of $\mathrm{C}$ and N (at $0 \% \mathrm{Mo}, 0.5 \% \mathrm{Si}, \mathrm{Mn}$ each) on the ledeburite and nitrogen void formation during solidification in $\mathrm{Fe}$ (1 bar) austenite stabilizing element, supports a void free solidification. The latter effect correlates with a reduced tendency of $\delta$-Ferrite formation due to the peritectic reaction. Fig. 2 indicates that grade $\mathrm{X} 40 \mathrm{CrMoVN} 16-2$ is above the limit of void free formation. Under industrial production conditions, two more factors counteract this effect. One is the necessary nucleation energy to form voids, and the second is the ferrostatic pressure with increases rapidly inside a cast ingot.

\subsection{Microstructures}

Fig. 3 shows the soft annealed microstructures of three selected alloys. The grade $\mathrm{X} 40 \mathrm{Cr} 14$ dominantly shows small spheric carbides as a result of the soft annealing process. Some irregularly shaped carbides inside the ferritic matrix (white arrow in Fig. 3a) indicate carbides, which may be the remainder of a ledeburitic solidification as described before. In contrast, huge carbides are visible in the microstructure of grade X90CrMoV18 (Fig. 3b) resulting from a massive ledeburitic reaction in good agreement with the Scheil calculations. In comparison, grade X30CrMoN15-1 exhibits only evenly distributed very fine carbides and nitrides, confirming that no or almost no ledeburite carbides were formed. It has to be noted that a diffusion annealing process can be used to re-establish equilibrium conditions and therefore remove parts of all of these large ledeburitic carbides.

\section{Prediction of the Retained Austenite Content}

\subsection{Calculation of the Retained Austenite Content at Room Temperature}

One of the key preconditions to calculate the retained austenite (RA) content is a reliable prediction of the $M_{s}$ temperature. Therefore, it is necessary to know the exact austenite composition prior to the quenching step, which, for carbide and nitride containing steels, is temperature dependent and not equal to the alloy composition. This is usually conducted with thermodynamic equilibrium calculations, which do not consider ingot segregations. Additionally, a usually empirically established $M_{s}$ formula is used, based on the austenite composition. Several such formulas, such as from e.g. [14-16] exist, but according to [8], they tend to significantly overestimate $M_{s}$ at lower temperatures. Optimized formulas, adapted to the specific thermodynamic calculation conditions for the RA composition, are necessary for a sufficient accuracy. Consequently, an adapted $\mathrm{M}_{\mathrm{s}}$ formula (1) with new factors for $\mathrm{C}, \mathrm{N}, \mathrm{Cr}$, and Mo based on the alloy compositions used in this investigation had to be established:

$$
\begin{aligned}
\mathrm{M}_{\mathrm{s}}= & 699.6-629.5 * \mathrm{C}-592.3 * \mathrm{~N}-7.5 * \mathrm{Si}-33 * \mathrm{Mn} \\
& -21 * \mathrm{Cr}-5.3 * \mathrm{Mo}-17 * \mathrm{Ni}-39 * \mathrm{~V}
\end{aligned}
$$


Fig. 3: Soft annealed microstructures of martensitic stainless steels a X40Cr14, bX90CrMoV18, cX30CrMoN15-1
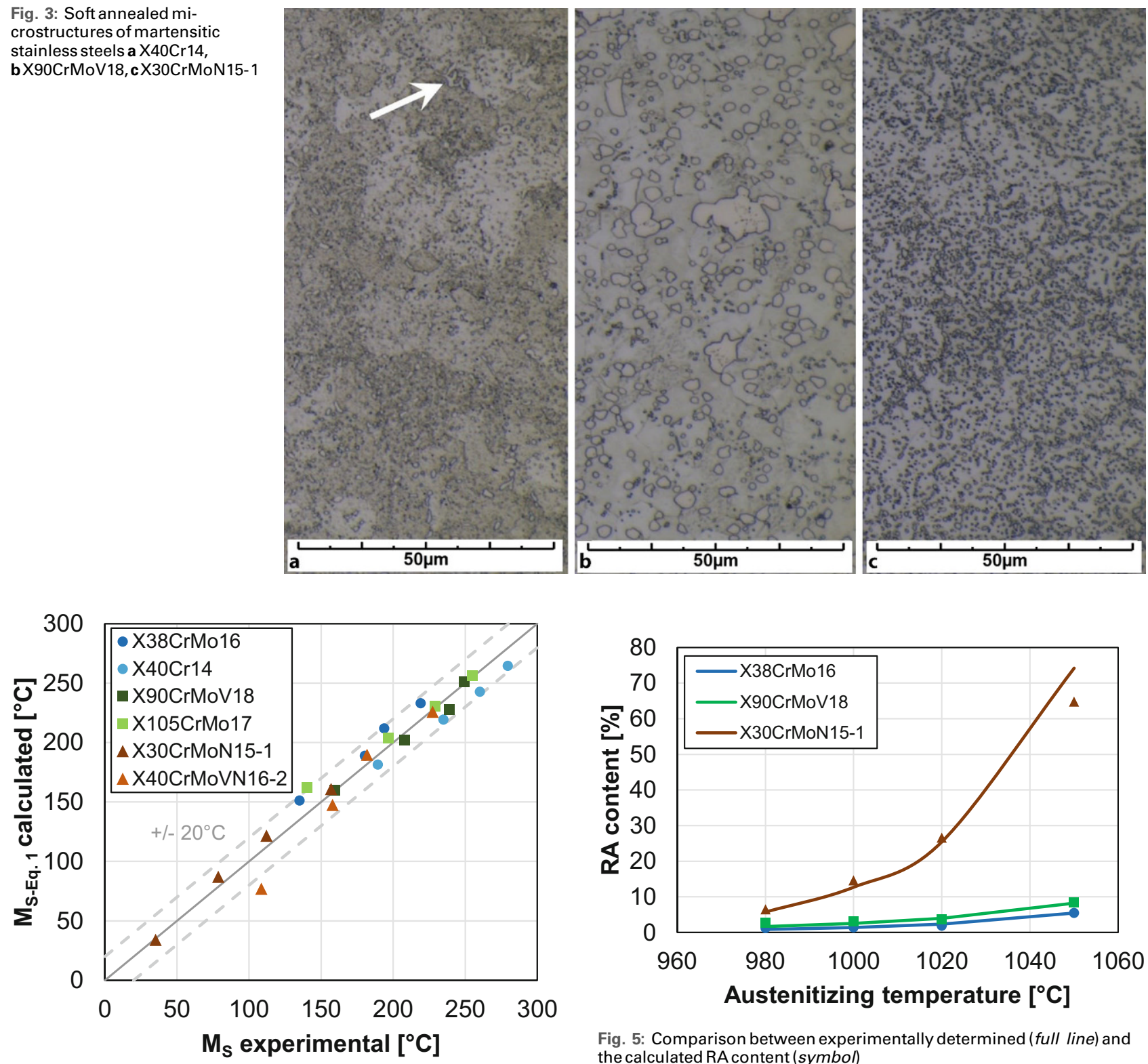

Fig. 4: Comparison between experimentally determined and calculated $\mathrm{M}$ s temperature according to equation (1)

Other factors were taken from [14-16]. The accuracy of the prediction can be taken from Fig. 4. Except for one value (X40CrMoVN16-2 at the highest austenitizing temperature), the predicted $\mathrm{M}_{\mathrm{s}}$ temperature $\left(\mathrm{M}_{\mathrm{s} \text {-Eq.1 }}\right.$ calculated) and measured $M_{s}$ temperature $\left(M_{s}\right.$ experimental) stay within a scatter band of about $20^{\circ} \mathrm{C}$.

The subsequent calculation of the martensite formation was performed according to the Koistinen-Marburger approach [4] using Eq. (2) and the experimentally determined k-values for these alloys from Table 1.

$$
V_{\alpha \prime}=1-e^{\left[-k \cdot\left(M_{S}-T_{Q}\right)\right]}
$$

Finally, the carbide content needs to be taken into consideration to determine the retained austenite content at

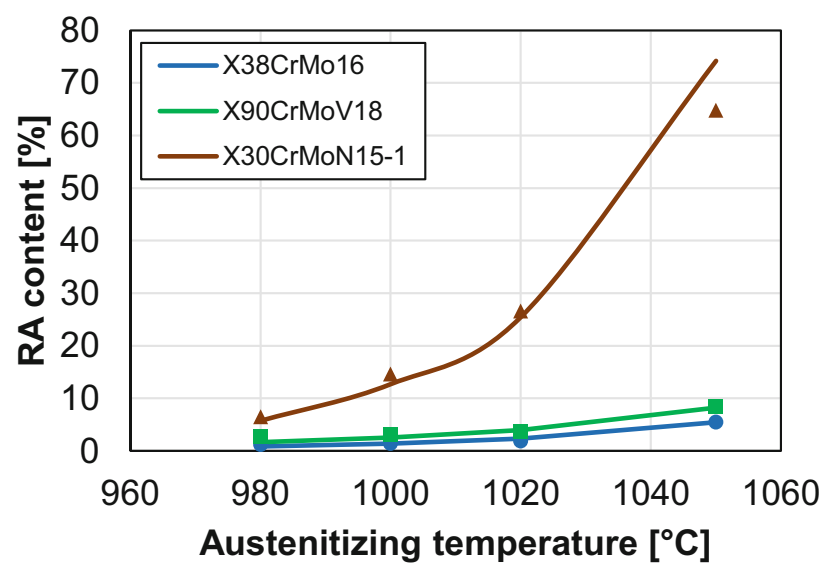

Fig. 5: Comparison between experimentally determined (full line) and the calculated RA content (symbol)

room temperature. A comparison of the calculated and experimentally determined retained austenite values is shown in Fig. 5 for three typical steels and different austenitizing temperatures. The increase in the RA content with rising austenitizing temperature is clearly visible for all three steels and most dominant for the $\mathrm{N}$ alloyed grade.

\subsection{Effect of the Quench Temperature on the Retained Austenite Content}

When quenching is interrupted at higher (quench) temperatures $T_{Q}$ than room temperature, either to safe process time or in the core of large workpieces despite reaching room temperature at the surface, the quenching \& tempering process becomes similar to the quenching \& partitioning process used for AHSS steels described e.g. in [6, 7] 


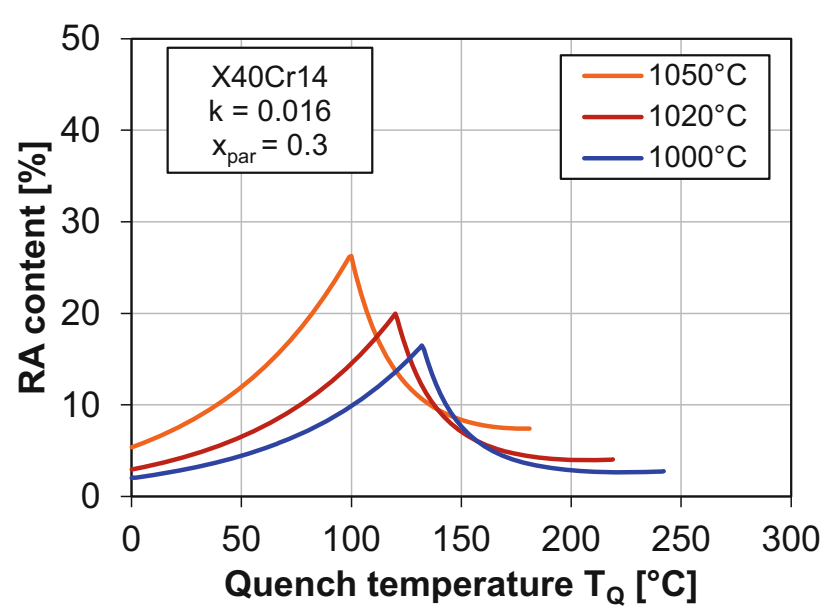

Fig. 6: Effect of the austenitizing temperature and the quench temperature on the retained austenite content, calculated with a modified CCEModel and partial partitioning

and is documented for martensitic stainless steels in [5, 8, 9]. The, at least partial, partitioning of $C$ and presumably also $\mathrm{N}$ from martensite into RA at low tempering temperatures (usually $<500^{\circ} \mathrm{C}$ ) leads to a stabilization of higher amounts of RA. Using the adapted CCE model from [8], the effect of the quench temperature can be calculated for different austenitizing temperatures.

Fig. 6 shows the typical results of such a simulation at the example of the steel $\mathrm{X} 40 \mathrm{Cr} 14$ using a partition factor of 0.3 based on experimental results from [9]. The RA content rises due to the partitioning effect with increased $T_{0}$ until a maximum is reached. At higher $T_{Q}$ the amount of $R A$ is too high, and thus the partitioning is no longer sufficient, to stabilize the RA to room temperature, and fresh martensite forms upon cooling from tempering thereby reducing the final RA content. Increasing the austenitizing temperature shifts the maximum RA content to lower quench temperatures and higher RA values. Higher quench temperatures therefore directly correspond with a rising RA instability as demonstrated e.g. in $[17,18]$.

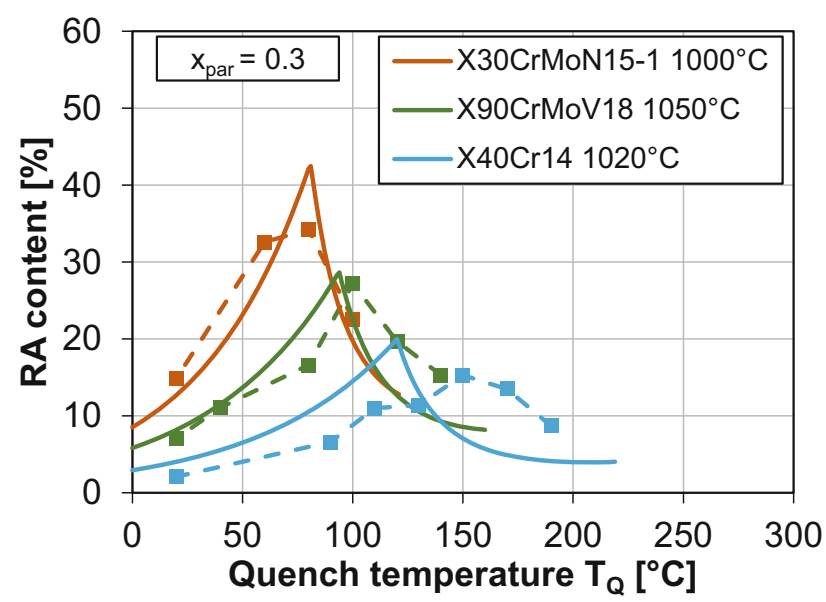

Fig. 7: Comparison between experimentally determined (full line) and the calculated RA content (dashed line with symbols) after partitioning at $300^{\circ} \mathrm{C}$ (modified CCE-model)
A comparison of predicted and measured RA contents as a function of the quench temperature for three steels with tempering (partitioning) at $300^{\circ} \mathrm{C}$ can be seen in Fig. 7 . Independent of the steel type (matrix, carbide rich of $\mathrm{N}$-alloyed), the results show reasonable concordance, thereby confirming the viability of the adapted model to martensitic stainless steels.

\section{Summary and Conclusions}

Modelling and simulation provide useful predictions and insights into the mechanisms of phase transformation and have become an indispensable tool in the development of new steels and the optimization of heat treatment processes. On the example of martensitic stainless steels, the following essential predictions can be conducted:

- Formation of ledeburitic carbide and nitrogen void formation and limits of nitrogen contents for conventionally produced steels

- Changes in the retained austenite content and indications for its stability as a function of heat treatment parameters such as austenitizing temperature and quench temperature, thereby confirming partitioning effects between the tempered martensite and the retained austenite

Acknowledgements. The authors gratefully acknowledge the funding of the project by voestalpine Böhler Edelstahl GmbH \& CoKG.

Funding. Open access funding provided by University of Applied Sciences Upper Austria.

Open Access This article is licensed under a Creative Commons Attribution 4.0 International License, which permits use, sharing, adaptation, distribution and reproduction in any medium or format, as long as you give appropriate credit to the original author(s) and the source, provide a link to the Creative Commons licence, and indicate if changes were made. The images or other third party material in this article are included in the article's Creative Commons licence, unless indicated otherwise in a credit line to the material. If material is not included in the article's Creative Commons licence and your intended use is not permitted by statutory regulation or exceeds the permitted use, you will need to obtain permission directly from the copyright holder. To view a copy of this licence, visit http://creativecommons.org/licenses/by/4.0/.

\section{References}

1. Lichtenegger, G., Schneider, R., Sammer, J., Schirninger, G., Würzinger, P., Neuherz, J.: Development of a nitrogen alloyed tool steel. In: Proc. of the 5th Int. Tooling Conference "Tool steels in the next century" Leoben (Austria), 29. Sept.-1. Oct. 1999. pp. 643-652. (1999)

2. Sammt, K., Sammer, J., Geckle, J., Liebfahrt, W.: Development rends of corrosion resistant plastic mould steels. In: Proc. of the 6th Int. Tooling Conference "The Use of Tool Steels: Experience and Research" Karlstad (Sweden), 10.-13. Sept. 2002. pp. 285-292. (2002)

3. Schneider, R., Sammt, K., Rabitsch, R., Haspl, M.: Heat treatment and properties of nitrogen alloyed martensitic corrosion resistant steels. In: Transactions of Materials and Heat Treatment-Proceedings of the 14th IFHTSE Congress Shanghai (P.R. China), 26.-28. Oct. 2004. pp. 582-587. (2004). Vol 25, No 5 
4. Koistinen, D.P., Marburger, R.E.: A general equation prescribing the extent of the austenite-martensite transformation in pure iron-carbon alloys and plain carbon steels. Acta Met. 7(1), 59-60 (1959)

5. Mola, J., De Cooman, B.C.: Quenching and partitioning ( $Q$ \& $P$ ) processing of martensitic stainless steel. Met. Mater. Trans. A 44(2), 70-84 (2013)

6. Speer, J.G., Matlock, D.K., De Cooman, B.C., Schroth, J.G.: Carbon partitioning into austenite after martensite transformation. Acta Mater 51, 2611-2622 (2003)

7. Speer, J.G., Edmonds, D.V., Rizzo, F.C., Matlock, D.K.: Partitioning from supersaturated plates of ferrite with applications to steel processing and fundamentals of the bainite formation. Curr. Opin. Solid. State. Mater. Sci. 8, 219-237 (2004)

8. Kresser, S., Schneider, R., Zunko, H., Sommitsch, C.: A model to predict the microstructural constituents after quenching and partitioning of martensitic stainless steels. J. Heat Treatm. Mat. 76(2), 120-131 (2021)

9. Huong, Q., De Cooman, B.C., Biermann, H., Mola, J.: Influence of martensite fraction on the stabilization of austenite in austeniticmartensitic stainless steels. Met. Mater. Trans A 47A(5), 1957-1959 (2016)

10. Petzow, G.: Metallographisches Keramographisches Plastographisches Ätzen. Gebrüder Bornträger Berlin-Verlag, Stuttgart (2006). ISBN 978-3-443-23014-2

11. Saller, G., Bernauer, J., Aichmayer, B., Kleber, S.: Influences on austenite formation and stability of high nitrogen alloyed cr-mn steels. Trans. Indian Inst. Met. 55(4), 169-175 (2002)
12. Stein, G., Menzel, J.: Herstellung, Weiterverarbeitung und technische Anwendungsmöglichkeiten massiv aufgestickter Stähle. In: Speidl, M.O., Uggowitzer, P.J. (eds.) Stickstofflegierte Stähle Ergebnisse der Werkstoff-Forschung. pp. 33-45. Thubal-Kain, Zürich (1991)

13. Medovar, B.I., Saenko, V., Grigorenko, G.M., Pomarin, M., Kumysh, V.I.: Arc-slag remelting of steel and alloys. Cambridge International Science Publishing, Cambridge (1996)

14. Schirra, M., Finkler, H.: Das Umwandlungsverhalten der Ferritischmartensitischen Stähle mit 8-14\% Cr. Wissenschaftliche Berichte FZKA, vol. 6730. Forschungszentrum Karlsruhe $\mathrm{GmbH}$, Karlsruhe (2002)

15. Steven, W., Haynes, A.G.: The temperature of formation of martensite and bainite in low-alloy steels. JISI 183(8), 349-359 (1956)

16. Andrews, K.W.: Empirical formulae for calculation of some transformation temperatures. JISI 203(7), 721-727 (1965)

17. Kaar, S., Krizan, D., Schneider, R., Sommitsch, C.: Impact of si and al on microstructural evolution and mechanical properties of lean medium manganese quenching and partitioning steels. Steel Res. Int. 91, 1 (2020). https://doi.org/10.1002/srin.202000181

18. Kaar, S., Krizan, D., Schneider, R., Béal, C., Sommitsch, C.: Effect of manganese on the structure-properties relationship of cold rolled AHSS treated y quenching and partitioning process. Metals 9, 1 (2019). https://doi.org/10.3390/met9101122

Publisher's Note. Springer Nature remains neutral with regard to jurisdictional claims in published maps and institutional affiliations. 